\title{
Poetry and leadership in light of ambiguity and logic of appropriateness
}

Article

Accepted Version

Xing, Y. and Liu, Y. (2015) Poetry and leadership in light of ambiguity and logic of appropriateness. Management and Organization Review, 11 (4). pp. 763-793. ISSN 1740-8784 doi: https://doi.org/10.1017/mor.2015.18 Available at https://centaur.reading.ac.uk/81621/

It is advisable to refer to the publisher's version if you intend to cite from the work. See Guidance on citing.

To link to this article DOI: http://dx.doi.org/10.1017/mor.2015.18

Publisher: Cambridge University Press

All outputs in CentAUR are protected by Intellectual Property Rights law, including copyright law. Copyright and IPR is retained by the creators or other copyright holders. Terms and conditions for use of this material are defined in the End User Agreement.

\section{www.reading.ac.uk/centaur}

\section{CentAUR}

Central Archive at the University of Reading

Reading's research outputs online 


\title{
Poetry and Leadership in Light of Ambiguity and Logic of Appropriateness
}

\begin{abstract}
This paper explores the relationship between poetry and leadership - in particular, how business leaders might leverage poetry in practice. Drawing on the theoretical lenses of logic of appropriateness and ambiguity, we suggest a conceptual model to understand the multilayered meaning of poetry, noting that poetry has four layers of meaning: the superficial meaning, the poet's evocative meaning, the reader's recasting into a modern situation, and the recipient's interpretation. Using the storytelling research method, we collected leadership narrative stories that indicate poetry as an effective communication tool in practicing leadership. From these data, we identify four approaches that leaders use to apply the multilayered meaning of poetry in contemporary business practice: drawing lessons from poets' experience through critical interpretation of the poem, inspiring leaders' heroic spirits, guiding leaders' rules of behavior, and adopting poetry as a tactic to influence others. Our study contributes to the argument of ambiguity as a source of intelligence and illuminates how poetry as an artistic form of story facilitates contemporary leadership practice in light of the logic of appropriateness framework.
\end{abstract}

\section{KEYWORDS:}

Ambiguity, logic of appropriateness, poetry, multilayered meaning, leadership, China 


\section{INTRODUCTION}

The notion of ambiguity is an essential concept in the decision-making process (March, 1978, 1994) and an important concept in the scholarly inquiry of behavioral theory of the firm (Argote \& Greve, 2007; Augier \& Prietula, 2007; Gavetti, Greve, Levinthal, \& Ocasio, 2012). Although conventional wisdom views ambiguity as disturbing, its hidden potential could inspire creativity and innovation, because it offers the imaginative space for multiple interpretations and meaning construction (March, 2010; March \& Olsen, 1976). With this study, we aim to unpack the concept of ambiguity and explore how it can be leveraged to exploit its potential benefits and beauty as a source of intelligence. In doing so, we apply March and Olsen's (1989) "logic of appropriateness" framework, conceptualized as a person's ability to shift swiftly among multiple identities and different interpretations.

Although some scholars have suggested that poetry is an effective storytelling tool to communicate and express complex emotions and ideas (Cunliffe, 2002; Darmer, 2006; Grisham, 2006; March, 2006), literature on poetry and management remains under development (Darmer \& Grisoni, 2011). In studying Chinese leaders' narratives about their leadership, we were surprised at how often ancient Chinese poetry appears in leadership storytelling. Inspired by James G. March's statement, "Leadership involves plumbing as well as poetry" (Augier, 2004: 173), our novel investigation juxtaposes poetry and leadership in light of ambiguity and logic of appropriateness.

March views poetry as having a compelling power to attract people to contemplate the beauties of life (Coutu, 2006). Poetry as an artistic form of stories may evoke a leader's emotion, imagination, and joy in practicing leadership. Ancient Chinese poetry in particular has important implications for leadership: in ancient China, most poets were virtually government officials. They incorporated their philosophical and political views in poems, but they were more often pragmatic than professional (Melvin, 2012). Building on this line of inquiry, we aim to investigate how business leaders might embrace and leverage the ambiguity of poetry to improve their leadership practices.

We argue that poetry has four layers of meaning: the superficial meaning, the poet's evocative meaning, the reader's recasting into a modern situation, and the recipient's interpretation. The logic of appropriateness is an underlying principle that explicates the multilayered meaning of poetry. When leaders recite an ancient poem to conceptualize their life story, they relive the poet's past experience. In this regard, leaders can recreate poetry by imagining the world embodied in the poem and bringing their own feelings and understanding to their storytelling. Thus, poetry helps leaders express their self-concept. Even poems of limited words can evoke a cascade of implications.

This study contributes to three main research areas. First, we add to the discussion of ambiguity in leadership literature, particularly because we see it illuminated by Chinese leaders as they use the many layers of meaning in poetry in their leadership. Our findings indicate that the logic of appropriateness is the underlying principle that explains contemporary business leaders' use of poetry. Second, we make an empirical contribution to the study of Chinese leadership by revealing ambiguity as a source of intelligence. Third, we believe that an understanding of how the logic of appropriateness influences multiple interpretations of poetry in Chinese leadership practices could be useful to leadership practice in other contexts, because poetry and the logic of appropriateness extend beyond cultural and institutional boundaries. To the best of our knowledge, we are the first to explore Chinese poetry and contemporary business leadership practice through the lens of ambiguity. By 
reflecting on poetry and linking with leaders' present experiences and ideals, we seek to contribute to the contemporary study of constructing leadership practice.

The remainder of this paper is organized as follows. We first review literature on ambiguity and the logic of appropriateness. We provide a brief introduction to ancient Chinese poetry and its implications by referring to both ancient and contemporary illustrations. Next, we elucidate the multiple layers of meanings of poetry through the lens of the logic of appropriateness, as building blocks for our arguments. We then discuss our research methodology and consider four ways of effectively applying poetry to contemporary leadership practices. We conclude with a conceptual model explicating the relationship between the logic of appropriateness and multilayered meanings of poetry and argue that studies of traditional culture and the understanding of ambiguity in leadership are mutually illuminating.

\section{Ambiguity and the logic of appropriateness}

The behavioral theory of the firm has inspired important management research (Argote \& Greve, 2007; Augier \& Prietula, 2007; Gavetti et al., 2012); within this line of scholarly inquiry, ambiguity is arguably an important concept (Cyert \& March, 1963; March, 1994). Conventional wisdom views ambiguity as disturbing because desires and interpretation are contradictory and causality is unfathomable; however, ambiguity can also be enlightening. March (1994: 178) defines ambiguity as "a lack of clarity or consistency in reality, causality, or intentionality," which underscores that alternative and multiple interpretations can simultaneously exist. March's (2010) most recent research also suggests that ambiguity can inspire creativity and innovation, implying its hidden, potentially positive impact. Similarly, other research suggests that ambiguity may lead to multiple interpretations (Santos \& Eisenhardt, 2009). Therefore, ambiguity could be used to augment understanding through imagination.

Pontikes's (2012) study, based on a longitudinal analysis of software organizations between 1992 and 2002, suggests that ambiguity can have either positive or negative implications, depending on the audience. Ambiguity might imply lack of clarity or lack of appeal to consumers, but it can also channel flexibility and appeal to venture capitalists. Therefore, ambiguity in reality leads to multiple interpretations of experience and identities that may be fundamentally obscure and ambivalent rather than merely uncertain. The development of multiple inconsistent interpretations depends largely on individuals' beliefs, preferences, and experiences, which allow them to switch from one interpretation to another (March, 1994). March and Olsen (1989) propose the logic of appropriateness to explain a person's swift shifting among multiple identities and different interpretations. In their argument, they use this concept to explain how a fraction of the relevant rules of behavior provided by a person's particular identity can be evoked in a particular place at a particular time. The logic of appropriateness framework suggests that as people make decisions, they explicitly or implicitly ask themselves, "What does a person like me do in a situation like this?" (March \& Olsen, 2004; Weber, Kopelman, \& Messick, 2004). It indicates that each identity provides rules of appropriate behavior in relevant situations by following the logic of appropriateness (March \& Olsen, 1989). Therefore, a primary factor affecting behavior is the process by which some rules, rather than others, are attended to in a particular situation (March \& Olsen, 1989). 
March and Olsen (1989) conceptualize key behavioral mechanisms as history-dependent processes of adaptation of particular rules through learning or selection. Rule-driven behaviors associated with successes or survivals are likely to be repeated, whereas those associated with failures are not. Because reality can be ambiguous, actors may find the rules and situations they encounter obscure. Therefore, fulfilling an identity by following appropriate rules often involves matching a changing and ambiguous set of contingent rules to a changing and ambiguous set of situations. The matching of identities, situations, and behavioral rules may be based on experience, expert knowledge, or intuition, in which case it is often called "recognition" to emphasize the cognitive process of pairing problem-solving action correctly to a problem situation (March \& Simon 1993). Rules of appropriateness are carriers of lessons from experiences that are encoded by either people drawing inferences from their own and others' experiences or differential reproduction of institutions (March \& Olsen, 1989).

\section{Poetry and contemporary implication}

March views poetry as having compelling power to attract people to contemplate the beauties of life (Coutu, 2006).

"Poetry is a way of contemplating and augmenting those beauties, as well as the absurdities of their presence in the dustbins of life. Poetry celebrates the senses; it celebrates the feelings in ways that other things don't. It's also a place where you can play with the splendor, sound, and combinatorics of words" (Coutu, 2006: 89).

As we noted previously, "leadership involves plumbing as well as poetry" (Augier, 2004: 173). Inspired by this analogy, we investigate the relationship between Chinese ancient poetry and contemporary leadership and explore how business leaders can leverage the ambiguity of poetry in their leadership practice.

In the Analects (Confucius, BC551- BC479 Chapter Yang Huo), Confucius uses poetry in four main ways: stimulating mind, improving self-contemplation, teaching the art of sociability, and developing critical interpretation. Confucius addresses how poetry can be used to guide various aspects of social and political life, considering poetry a means of selfrealization and the attainment of the perfect state. He treats poetry as a method of training people and establishing relations in society; indeed, he believes that those well-read in poetry should become efficient administrators. "All the Chinese scholars and officials were poets, or pretended to be" (Lin, 1936: 28).

Chinese poets used the ambiguous meaning of poetry as an effective communication tool, such as to express their true feelings indirectly. In ancient China, a high peak of classical Chinese poetry occurred during Tang Dynasty (618-907), when poetry became part of the Imperial examinations to confer government posts. It is not surprising, therefore, that traditional China poetry is endued with political overtones used to express feelings, ambitions, and ideals.

Poetry scholars have identified six major literary devices employed in ancient Chinese poetry: feng (风, folk music of the states), ya (雅, court hymns), song (颂, eulogies), fu (赋, straightforward narrative), bi (比, explicit comparisons), and xing (兴, metaphor). Metaphor is one means of poetry. Metaphor is useful from an epistemological perspective as a basis for 
analogical reasoning in organizations, because of its cognitively prescriptive role in knowledge imagery and dissemination (Oswick, Keenoy, \& Grant, 2002). Thus, metaphor may occur in poetry functions as a literary device (Bourgeois \& Pinder, 1983) for making sense of personal perspective, and as the end of analytical exercise on enhancing explicit understanding of life (Morgan, 1997). Moreover, poetry is the departure point from which readers' imagination can convey poets' values, dreams, beliefs, and thoughts beyond the depicted scenery.

In Huifeng Cihua (惠风词话 Comments on Ci Poetry), Kuang Zhouyi (1859-1926) claims to find genuine emotion in poets, in that when composing poetry, they express their sincere feelings and career ambitions. Miao (1979) extends Kuang's idea and suggests an autobiographical approach to study Chinese poets' intentions and ideals behind the aesthetic form and superficial words. Through the words and sentences, we can discern poets' identity and character. Instead of expressing their ambitions directly, poets use delicate language to depict scenery to create certain moods and atmosphere. In doing so, they imply their social experiences and will within the atmosphere (Liu, 1962; Miao, 1979; Hightower \& Yeh, 1998). Later generations who agree and emotionally resonate with the poets' values might be inspired and stimulated. Beyond the utility of metaphor, Chinese poetry can also embody poets' identity and character, imply their will and emotion, arouse resonance between the poets and their readers, and enlighten their recipients. The historical development of Chinese poetry is illustrated in Appendix.

Scholars recognize that poetry can be used in organizational and management research to advance understanding of management practices (Darmer \& Grisoni, 2011). For example, poetry can inspire, stimulate, and develop businesspeople and solve problems within the research process (Darmer, 2006). The creative use of poetry can illuminate unconscious processes and organizational issues involving emotional discomfort (Grisoni \& Kirk, 2006). One recent study shows that poetic writings can facilitate participative inquiry to examine equality and diversity (Page, Grisoni, \& Turner, 2013). In addition, researchers have noted the shared wisdom of traditional Asian thoughts and North American organizational theories (Rhee, 2010). As the imaginary illustration of "classical Chinese thinkers meet James March" (Rhee, 2010) shows, the striking similarity and affinity between the two implies that the traditional Asian thoughts can shed light on contemporary leadership practices.

Therefore, we use ancient poetry as a virtual vehicle to explore the imagination, creativity, insight, and will of leadership. Chinese poetry as an artistic form of stories can evoke leaders' emotion and imagination. We believe traditional culture and philosophical foundations have significant bearing on contemporary leadership practices (Liu, Xing, \& Starik, 2012). We suggest that the logic of appropriateness is the underlying principle that leaders resort to when applying ancient poetry to leadership practices. Our research findings resonate with recent philosophical and epistemological arguments in embracing Eastern philosophy of wisdom (Li, 2012).

\section{The logic of appropriateness and multiple layers of meanings of poetry}

We subscribe to the notion of ambiguity as open-ended multiple interpretations and elaborate our argument with respect to ambiguity embedded in ancient poems. In this section, we discuss the properties of ancient Chinese poetry and its relationship to ambiguity. Traditional Chinese poetry uses concise rhymed words endowed with the beauty of ambiguity, which 
offer ample opportunities for poets and readers to reflect on and interpret the poems and associate superficial meanings their own experiences, desires, preferences, and identities. In this paper, we explain how ambiguity enables contemporary readers to comprehend poems through various meaning construction processes following the logic of appropriateness.

Chinese poetry scholar, philosopher, and educator Wang Kuowei (1877-1927) suggests that the best poems should not only deliver the poet's meaning but also resonate with readers' feelings. To this end, poets deliberately construct ambiguous contexts and multiple layers of meanings in their poems. Building on the logic of appropriateness, we suggest that comprehension and interpretation of Chinese poetry encompass four layers of meaning: the superficial layer, the poet's intended and evocative meaning, the reader's recasting into modern situations, and the recipient's interpretation of the readers' recontextualization of poetry (note that on occasion, readers and recipients may be the same).

INSERT TABLE 1 ABOUT HERE

We elaborate the multiple layers of meanings of poetry in Table 1, illustrating how poetry might be interpreted by different people in different situations. Table 1 also illustrates the four layers of meaning by applying the logic of appropriateness in the context of both ancient literary and contemporary situations. Wang Kuowei (1877- 1927) notes people's three realms of great learning as an example. As shown in Table 1, he chose three Chinese classical poems from the Song Dynasty (960-1279) and drew out several lines of each to elucidate the process of great learning by constructing the divergent meanings with his own interpretations.

For the poets' own purpose, neither the superficial meanings of the poems or the intended implication by the poets are linked to learning. However, Wang's emotion evoked by each poem resonated with his own experience at various stages of learning, which enabled him to extend a divergent meaning of each poem and transposed the meaning into a learning context. By applying the logic of appropriateness, the reader interprets the poets' evocative meaning by recasting it in new situations.

The ambiguity of these poems enabled Wang as a reader to infuse or recast new meanings into them. Here, ambiguity can be the source of intelligence that extends divergent meanings to the poems and inspires the readers' efforts to comprehend the new meanings.

Chinese people care about employing the ambiguous or divergent meaning of Chinese poems. This pragmatic feature of Chinese poetry allows modern Chinese leaders to infuse poems with new meaning that expresses their own will and ambition. At the same time, poetry might enhance a leader's charisma while making the language more powerful and convincing. The historical background of the poem might also evoke cultural heritage and provide support to the leaders who use the poem in another context. Due to ambiguity, Chinese poetry has been interpreted and understood in various ways by readers in later generations. Chinese poetry is as romantic as philosophical in content, as passionate as restrained in feeling. Perhaps this is the reason that Chinese poetry has contemporaneity for Chinese readers.

\section{RESEARCH METHODLOGY}

Because of the nature of our research questions, we chose to use the narrative/storytelling research method (Gabriel \& Connell, 2010). This method embraces the "linguistic turn" in social science scholarly inquiry (Phillips \& Oswick, 2012). Scholars and practitioners have exhibited increased interest in the applicability of storytelling leadership research (e.g., 
Dailey \& Browning, 2014; Sims, 2005, 2010). Their studies make theoretical and methodological contributions by revealing the nuances and underlying logic of leadership behaviors (Bryman, 2004), resulting in a rich body of knowledge unavailable through other methods of analysis (Rosile, Boje, Carlon, Downs, \& Saylors, 2013).

Ambiguity is a central component of poetry, an artistic form of story (Liu et al., 2012). A poem can leave ample space for readers' imagination and interpretation. It might engender emotional resonance between writer and reader unconsciously. For example, a poem of sustainability invites individual actions by awakening awareness of environmental challenges beyond time and space (Whiteman, 1997).

We collected our data in two phases. In the past six years we carried out in-depth interviews (Wengraf, 2001) with more than 60 Chinese banking managers, examining their understanding of their own leadership. We found that 20 of the 60 managers spontaneously mentioned poems or used poetic discourse in their narratives. Thus, we decided to explore this field in which little is currently understood. Thus the purpose of the study requires a logic of discovery rather than a logic of proof (Diesing, 1971). In the first phase, we focused on leadership practice and storytelling in 20 in-depth interviews (Wengraf, 2001) with senior managers from Chinese professional services firms such as commercial banks, investment banks, asset management firms, consulting firms, and information technology firms. During the narrative research, we discerned that poetry emerged from time to time during leaders' narrative storytelling about their leadership practices. Our curiosity about the relationship between poetry and leadership led us to the second phase of data collection, which had a tailored focus on poetry. We interviewed another 30 leaders in Chinese professional service firms, including international accounting firms, consulting firms, and leading financial institutions. This sample represents a more diverse collection of Chinese firms, including state-owned, privatized, and entrepreneurial sectors (Walder, 2011).

Because our purpose is to examine how poetry affects leadership practice, rather than focusing on leaders' use of poetry as a tool to communicate with interviewers, we focused on how leaders intentionally or unintentionally use poetry at a strategic or tactical level of practice. During the first phase of data collection, several leaders quoted poetry a few times in their interviews, though mostly as a communication tool. Therefore, in the second phase, we particularly asked leaders how and to what extent poetry might influence leadership by soliciting concrete narrative stories.

We selected managers on the basis of their willingness and the diversity of their roles, though we were not attempting to select any kind of random or stratified sample. Each interview lasted one to two hours. All the interviews were tape recorded and subsequently transcribed. Our analysis reveals that 16 business leaders referred to poetry's influence on leadership practice. $^{1}$

We used our four-layer poetry meaning categorizations as a conceptual guide to map out the poems mentioned in our data set. We first read the focal poem to grasp the meaning at the superficial layer. We then traced its historical context and assembled relevant background materials to interpret the poet's meaning. Last, we analyzed the business leader's contextual environment to discern the divergent meaning. The data analysis process is discursive rather than linear. When we found any additional version of interpretation of the original poem by later generations, we juxtaposed it against the accumulated understandings of this poem. The interpretations might be divergent themselves, because readers might carry some implicit assumptions given their contextual background, identities, and experiences. We subscribe to 
the social constructivism approach (Cunliffe, 2008) and the viewpoint that "the 'real' world may itself be a product of social construction, thus not so much discovered as invented" (March, 1994: 179). Therefore, we highlight the importance of context and the contextualization process (Tsui, 2007, 2009) in performing our data analysis. Table 2 summarizes our data analysis by outlining four categories of leaders' application of poetry to their leadership practice.

\section{FINDINGS}

In this section, we present illustrative examples of poetry that business leaders used to delineate the functions of contemporary management and organization with a particular lens on leadership practice. We were enlightened by March's (2010) argument that ambiguity can play an important positive role in organizations. In the context of learning, March distinguishes two general modes-low-intellectual and high-intellectual learning-and suggests storytelling as an effective mechanism of high-intellectual learning by using narrative to give meaning to historical events (March, 2010). The overarching theme from our analysis is ambiguity inherently embedded in poetry. Business leaders can deploy ancient poetry for the purpose of envisioning and practicing leadership by leveraging the relationship of ambiguity and intelligence.

By performing systematic data analysis of narratives/storytelling from business leaders, we discovered four ways of applying ancient poetry in contemporary business. March's (1994) logic of appropriateness offers the theoretical foundation that underpins our study. In particular, we find that the illumination happens mainly on two levels: the managers' individual level, involving drawing lessons from poets' experience through critical interpretation of the poem, inspiring managers' heroic spirits, and guiding managers' rule of behavior; and the organization level, where poetry can be used as a tactic to influence others (e.g., educate employees, win trust from customers).

\section{Drawing lessons from poets' experience through critical interpretation of the poem}

Kent is chief executive officer of a management consulting firm in China. He did not attend an elite university; he has an easy-going approach in dealing with people. He enjoys learning from historical accounts. He mentioned Wang Anshi, a great reformist in the Song Dynasty in our interview, who carried out institutional and economic reform as prime minister, though in the end he was strongly opposed by the conservative party and his reform was forbidden.

Kent notes:

His purpose and policy were advantageous to the country development, but I personally question his leadership. I do not think he could critically examine his failure or recognize his weakness.

Then Kent recited one of Wang Anshi’s famous poems, "2 "Reading History”:

What is really valuable is usually ignored in the historical record; 糟粕所传非粹美 
What the best painter cannot show is figural spirit; 丹青难写是精神

How can these people with common and ordinary sense understand thoroughly the thought of talented people of superior attainment, 区区岂尽高贤意

What they can tell (in their historical record or painting) is only superficial things recorded in the books or appearance. 独守千秋纸上尘

In evaluating the poem, Kent held a critical viewpoint from his leadership perspective:

The poem reads beautifully and profoundly—but with prejudice and arrogance. It revealed Wang Anshi's judgment on his initiated reform and consequences. Wang attributed the reason for reform failure to others being conservative and ignorant without questioning his own behavior. In fact, he had problematic leadership skill and failed in cooperation. If you read his biography, you will find he was not capable of finding or cultivating talented followers and paid little attention to the details. In his poem he disdained others and never tried to convince his opponents to stand on his side; rather, he pushed them further away. So Wang was superior in knowledge but poor in practicing leadership.

Kent used critical reflexivity to interpret the poem by straying from the poet's viewpoint, examining and questioning the understanding and assumptions of the poem. In so doing, Kent encouraged audiences to think more critically about Wang Anshi's personal experience and leadership practice and to engage in dialogue that is critical to our understanding of the legitimacy of the poet's leadership as a reformist. He then compared Wang Anshi with another politician in Ming Dynasty to reflect his understanding of an effective leader:

As a leader, I admire Wang Yangming, who advocated "to know is easy, to act is hard." He was invincible as a general, knowledgeable as a scholar, and diplomatic as a politician. This guy is too perfect to learn, that is why Togo Heihachiro said, "My whole life followed the example of Yangming."

In contrast, Tony, the senior manager of a banking asset management company, shared an alternative reading of the same poem by Wang Anshi. Tony effectively helped many banks address nonperforming assets. However, he was disappointed that there were few people who really appreciated the value of his work. In many banking experts' view, a nonperforming asset is like a frozen Popsicle, which should be eaten quickly before it melts to worthlessness. However, to Tony, it is more like a tree root left after wind has destroyed the tree. He noted three levels of addressing the problem, based on his own experience:

The first level is to burn the root, as farmers do. The second level is to carve the root into a souvenir to sell it on the tourist market. These two levels are simple ways to reclaim the tree's original value for the most part, which parallels what most ordinary bankers do with a nonperforming asset. The third level is to take out the whole root and carve it into delicate artwork. In this way, it can become much more valuable than the tree itself. I think that in dealing with nonperforming assets, we should aim to become artists. 
However, due to the lack of proper merit system to assess this industry, no one knows how to distinguish the nonperforming asset as an artist's work or a farmer's. Thus, I have a deeper understanding and feeling towards a poem of Wang Anshi than anyone else ‘区区岂尽高贤意，独守千秋纸上尘” this is why Wang Anshi is a capable leader.

The poem seems to be Tony's self-evaluation. He and the poet share similar experiences and situations: Tony saw himself as being an artist in dealing with nonperforming assets but ignored and devalued by others, just as Wang Anshi attained great achievement but received little appreciation.

It is worthwhile to note that Tony accords the poem sympathy and agreement but Kent criticizes it. In Kent's and Tony's different interpretations of the poem, Wang Anshi may be portrayed as a proud but pioneering politician or an aloof but determined reformist, thus demonstrating the use of the logic of appropriateness in multiple interpretations of a poem.

Traditionally, as Wang Anshi's reform on the country's economic and institutional development was recognized by later generations, people like Tony tended to note his talent and take his perspective. However, as a chief executive officer carrying out reforms for his company, Kent was concerned with the rule-driven behavior associated with why the poet failed in his reforms. According to March's (1994) logic of appropriateness, rule-driven behavior associated with successes is likely to be repeated, whereas that associated with failures are not. Therefore, the poem, which the poet intended to express his indignation, selfpity, and fidelity to his reform, only reveals the poet's proud and poor leadership, according to Kent.

Chinese poems cannot be studied without knowing the poets' life and experience. Chinese poets prefer the immediate presentation of sensory images or history without the first-person speaker intruding on the scene. In Wang's poem, he speaks of the history and we learn to know him in terms of the history which he talks about. The less he speaks of himself, the more he reveals of himself. This ambivalent expression helps managers and their audiences learn from the poet's experience.

\section{Inspiring managers' heroic spirits}

Peter is deputy manager of a Chinese commercial bank, Beijing branch, in charge of marketing business. Before he joined the commercial bank, he worked in a state-owned company as a department manager. Although he considered the work stable and comfortable, he felt his capability was constrained:

I could not see any space for me developing my capability. Although my position as a department manager was secure, I believe others would also be safe in my position. That means I could not bring any more value to the company; therefore, I was not irreplaceable. 
After much consideration, Peter decided to resign from his department manager job and accept a job from a publicly listed investment bank in China as a manager in charge of a new department. In his first job, the promotion was slow but secure, and the work was simple; in the new one, the job is more challenging and requires a great deal of responsibility. He attributed his "boldness in decision making" to his "heroic complex" and the influence of the Hao Fang school of poetry on his life:

I enjoy reading the poetry of Hao Fang school in the Song Dynasty as opposed to the soft one from my childhood. I highly admire Su Shi, who always held a generous and openminded attitude in dealing with predicaments. Moreover, he never gave up his patriotic aspiration. One of my favorite poems of Su Shi ... is:

I'll bend my bow like a full moon, 会挽雕弓如满月

Aiming northwest, 西北望

I will shoot down the fierce Wolf from the sky 射天狼

I can feel his bighearted mind and spirit, and I believe a real man should be like him. The more heroic poem you read, the broader spirit you will have. Therefore, Su Shi's poem inspired me at a time of frustration and gave me boldness to dare to make a change [quit his secure job as department manager].

This use of poetry empowers the readers to achieve. In this story, Peter was inspired by the poet's heroic spirit and instilled with courage to address his personal situation.

The poem was composed by Su Shi, a famous Chinese poet and statesman of the Song Dynasty (960-1279). He founded the Hao Fang school of poetry, which cultivated an attitude of heroic abandon. His political enemies had him exiled to Mi Zhou; subsequently, a battle took place between his country and Jin Xia. His poem indicates his wish, ambitions, and courage to lead the fight with enemies. The poem expressed the feelings it aroused in him. The "Fierce Wolf" is Sirius in Chinese, which is located northwest of the poet's country-a metaphor for Jin Xia, which is northwest of Song.

Giles (1923, p. 50) defines Chinese poetry as "emotion expressed in words," but "the meaning should lie beyond the words," and "the reader should have to think it out." That is to say, most Chinese poetry is ambiguous and impressionistic. Instead of announcing directly his ambition of fighting Jin Xia, Su Shi portrayed three series of actions that gave an impressionistic perspective to arouse heroic feeling in the readers: "bend my bow like a full moon," "aiming northwest," and "to shoot the fierce Wolf from the sky." Readers can feel the power and spontaneously transfer the feeling to their own lives. In relishing his favorite lines of the poem, Peter attributed poetry as an impetus for his decision of leaving a comfortable but constrained company for a young and energetic one: Su Shi's poem gave him boldness to dare to make a change. 


\section{Guiding leaders' rule of behavior}

John, a general manager of a bank's city branch, had just been promoted as senior manager of a state-owned bank's province branch. Soon after his arrival, he proposed a strategic collaboration with other financial institutions to help the bank improve its competitive capability. He worked hard to establish the collaboration, and later it proved to be of benefit to the bank in terms of increased annual revenue. However, his innovative idea was criticized by a person who blamed him for destroying the steady development of the bank and causing panic among staff members. In explaining his intention of carrying out the change, he used a poem to explain his idea:

Some people are very conservative, so they object to my action. But I believe as time goes by, history will prove the wisdom of this action, for I believe that it will benefit bank development. Thus, we must take this opportunity to establish the collaboration. I am not in pursuit of a successful career for myself but want to do some good things to develop my bank. If you consider too many unimportant things and hesitate to take action, we will definitely lose the chance. Because

\section{If a bud opens, gather it 花开堪折直须折}

\section{Lest you but wait for an empty bough. 莫待无花空折枝}

Don't wait until flowers faded and you regret losing the opportunity.'

The poem reflects the poet's philosophy of life: young people should treasure their time and lovers. John recontextualized the poem to guide his dealing with the management predicament. Thus, John suggested that if one really appreciates flowers, a person should treasure them while they bloom, rather than regret their passing after they fade. In fitting the poem to his modern situation, John used it to explain his philosophy. As the audience, our understanding of him then goes beyond the story about carrying out collaboration; we also learn that despite encountering opposition and criticism, he takes a sensitive and lively perspective on his work and enjoys it.

Similar to John, David adopted the philosophic thought implied in a poem to guide his leadership. The impact of poetry on David was even more profound than on John: David went beyond the superficial meaning and evocative meaning of the poem, to embrace the poet's leadership and rule of behavior. David is partner of privately owned logistics company specializing in human resources, finance, and purchasing. Founded by three partners in 1997, David attributes his firm's success mainly to the collaboration among founding partners. It is not uncommon for privately owned firms to split due to the diverging interests of their founders. As David elaborated,

Collaboration is a process of seeking compromise. Personalities and characters largely influence the collaboration process. Some might dominate, while others need to cooperate. The key is compromise ... in the team for the benefit of the firm.

Then David amplified his talk on a historical leader whom he admired deeply: 
Zeng Guofan was a wise leader. Many of his thoughts could be applied to contemporary leadership. Zeng possesses the wisdom to make compromise, because sometimes making compromise needs wisdom. He raised the army to fight effectively against the Taiping rebellion and restored the stability of Qing Dynasty. I identify deeply with his most famous poem:

To enjoy when the flower is budding,

To appreciate when the moon is yet to become round 花未尽开月未圆

This reveals what he believed to be the highest state of life. Flowers wither after bloom, and the moon becomes incomplete after it is full. This poem explains why he forwardly demobilized after he won his last battle. Though he said, "Enjoy a scholarly life after hundreds of battles 百战归来再读书, ” in fact, he knew that ... he would have met with jealousy and suspicion from the emperor and ultimately be killed. He was wise enough to dismiss his army, and therefore, he experienced a safe end. As leaders, we should learn from him, particularly from his perfect integration of several ... roles: invincible military general, humble Confucian scholar, and sagacious official. From his poems, we know the secret of his success: being knowledgeable enough to compromise and to enjoy the second best rather than perfection, and he secured the long duration of his eminent family. He was not aggressive and never blew his own horn when talking to others but was capable of exerting a subtle influence on people. He was skillful in dealing with conflicts. I personally learned a lot from him."

To David, Zeng Guofan's poem describes scenery on the surface but implies his life philosophy in its implied meaning. The poem is ambiguous, in that the poet does not explain why he enjoys budding flower and incomplete moon. However, by exploring the profound meaning beyond the words, David understood the poet's philosophic mind from the poem and admires his behavior, which he interprets as "enjoy the second best rather than perfection." Similarly, in Zeng Guofan's other poem, as mentioned by David ("enjoy a scholarly life after hundreds of battles"), the poet's feeling seems ambiguous. Therefore, readers might ask why a general who has won hundreds of battles did not want to enjoy his glory or continue to pursue victory but rather pursue the relatively simple life as a scholar. Linking his poem with his experience, we perceive that the poet did not want to incur the emperor's jealousy or suspicion as a result of his great victory. This ambiguous expression should help readers understand poet's experience and thought and, in turn, deepen readers' appreciation of the poem.

According to March and Olsen (1989), fitting a rule to a situation is an exercise in establishing appropriateness through metaphorical reasoning of similarity. In David's opinion, under the circumstances Zeng Guofan faced, Zeng's rule of behavior allowed him to understand his identity clearly and choose to make a compromise and transform flexibly (give up his identity as a general and choose the identity of a scholar). By analogizing his own situation with the poet, David discovered and accepted the implications beyond the words of the poems, and he matched the poet's rule to his own situation. 
Unlike the previous poems, this poem influences managers not by evoking a mood or inspiring a heroic spirit but by wisely cautioning the manager. Therefore, in this case, Chinese poetry is reflective, and the philosophy is mainly concerned with the poet's place in the world. This spirit of harmony and compromise is the inspiration causing readers spontaneously to follow.

\section{Adopting poetry as a tactic to influence others}

Hennery is vice president in a commercial bank. He was promoted quickly due to his excellent performance in the bank's marketing business. In recalling his previous leading experience as head of marketing, he shared with us how he used poetry to promote employees' courage and enthusiasm:

In my bank, the marketing unit is a core department, so marketing managers are similar to generals leading troops conquering territory. Our bank is in fast development, so the marketing task and the pressure increase each year. Therefore, I spent a lot effort promoting employees' combative spirits. In our meetings, I ... use poems to stimulate them, such as my favorite Wang Yangming poem:

“The weal and woe which stay not in mind will pass by. 险夷原不滞胸中

Just as the floating cloud sailing across the sky. 何异浮云过太空

I cross billows for miles and miles at night. 夜静海涛三万里

Like an immortal, cane in hand, riding moonlight.”月明飞锡下天风

Wang's poem is very inspiring. He was a man who could really put his knowledge into action. Our pursuing knowledge is limitless; thus, our capability should be boundless.... We beat difficulties instead of being beaten by difficulties. I understand you have heavy pressure and sacrifice time, effort, and even family, but we should choose to march into battle rather than escape. Employees do not like to hear hackneyed and stereotyped expressions, so when I inspire them with historical stories and poems, they are touched. I usually choose these heroic poems to lift their spirits. In addition to monetary rewards, employees need cultural promoting."

It is worthwhile to note that in our interviews, Wang Yangming was mentioned twice by different managers. Wang Yangming was a Chinese idealist philosopher, official, educator, calligraphist, and general during the Ming Dynasty. In the poem, he states that hardship and dangers are like a floating cloud that will pass by and will not bother him. The poet uses the impressionistic and ambiguous expression "as the floating cloud sailing across the sky" 何异 浮云过太空 to evoke a mood or a thought that did not directly say what the poet actually did. Readers value the poem for what it suggests or evokes rather than for what it actually says. 
The poem raises readers to the state that enables them to continue the theme in their minds. In this way, the poem is at once inspired and inspiring, for it implies collaboration between the poet and his readers.

In Hennery's story, he admired Wang Yangming not just for his poem but for his personality and achievement, which he believed are worthy of emulation by employees. Therefore, the leader recontextualized the poem into his modern situation but still maintained the poet's personality. This approach follows the logic of appropriateness to match the identity of the poet to the leader's situated interpretation.

Like Hennery, Leo, director of a national development bank, also resorted to poetry in training young staff members in his bank,

I usually use some poetry to inspire my young employees like Fan Zhongyan's poem

Bear the hardship and bitterness before others, 先天下之忧而忧,

Enjoy comfort and happiness after others'后天下之乐而乐

To those young people, we really should use this to encourage their spirits. Above all, you should have this kind of will that "I work hard not only for my own sake but that I have responsibility for my organization and I should contribute to the society." Fan Zhongyan's poem gives readers vigor and broader mind encouraging them to stand on a superior level. I think young people should be cultivated to appreciate his poetry and to agree with his spirits.'

Fan Zhongyan was a famous statesman in the Song Dynasty. In the poem, the poet did not specify his contribution to his country; though it is ambiguous, readers still value and are touched by what the poet suggests, rather than needing to clarify what the poet actually said. The leader used the poem to inspire employees in the hope that they would agree with the poet's ideal to put the self after the organization and society and therefore to make a heartfelt meaningful contribution.

Hennery and Leo leveraged poetry as strategic tactics beyond the individual level to educate their employees. They used poetry to inspire and stimulate employees, resonating with the fearlessness and devotion to the nation. In so doing, such an emotional evocation might be transferred to the employees' present situation.

Similarly, Ning used poetry to win customer's favor and buy-in. Ning is a key account manager of a national research and design institute in the aerospace industry. Her department is in charge of conducting experiments on behalf of a third-party organization. Therefore, one of her major tasks is to communicate with key account customers. She shared a story about using a poem to win her customer's approval:

There was a woman in her forties who was very picky. She easily lost patience and became a headache for my employees. I had to handle this customer by myself. I noticed she was fond of dressing up and looked younger than her real age. So one time, I told her 
privately, "You left me very good impression at the first sight; you know, you just look like Wang Xifeng (character of a classic novel Dream of the Red Chamber): very capable and charming. Every time I see you, I recollect the poem "Her impressive manner veiled in her rosy cheek.” 粉面含春威不露. Hearing this, she became very delighted and not so distant any more. We chatted a lot, and finally, she told me, "In fact, what your department has done is very professional, there is nothing to improve."

The poem is from one of China's Four Great Classical Novels Dream of the Red Chamber (红楼梦). It praises Wang Xifeng's beauty and impressive manner; she was a charming, capable, clever woman in charge of a noble family. The manager used the poem as a communicative tool to gain favor and trust from her customer. The ambiguous expression of the beauty in the poem allows Ning to graft the praise onto her customer in an acceptable manner. The pair-matching of the recipient's identities with the character in the poetry fits with the situation - the underlying logic of appropriateness. This narrative indicates that leaders can effectively leverage poetry in dealing with customers.

\section{DISCUSSION AND CONCLUSION}

In this section, we consolidate our findings and relate them systematically to the conceptual framework indicated in Figure 1 to elucidate how contemporary leaders can interpret, derive and leverage multilayered meanings of poetry. Essentially, the conceptual framework is a multilevel model consisting of both individual- and organization-level mechanisms.

\section{INSERT FIGURE 1 ABOUT HERE}

Layer 1 is the textual superficial meaning of poetry, which is written in a concise and artistic way. Layer 2 contains the poet's intended and evocative meaning, which corresponds to the poet's context and personal background. Layers 3 and 4 are derived from Layer 2. They follow the logic of appropriateness to arrive at multiple interpretations based on the audience's identities and experiences in particular situations. Layer 3 is leaders (readers)' recasting of the poetry into modern situations. As our findings show, it is possible that leaders stay at Layer 3 to critically reflect and learn from the poet. We argue this scenario manifests the individual-level mechanism.

However, there is another possibility: Layer 4 is when leaders use poetry to influence employees or customers of the organization. This interpretation process follows the logic of appropriateness. Recipients might interpret a leader's usage of poetry according to their own identities, desires, and experiences. This scenario illustrates the organizational level mechanism and use of poetry. Admittedly, poetry interpretation is not a linear process, as our conceptual model indicates from Layer 3 to Layer 4. Recipients can consciously relate to the original poetry and poet as the Layer 2 indicates. However, we argue that it is possible for leaders to use poetry as a tactic to achieve organizational purposes, such as motivating employees and winning customers. The beauty of ambiguity and the possibility of multiple interpretations provide leaders with the toolkit to exploit ambiguity as a source of intelligence. Effectively using poetry calls for skilful and artful leadership qualities.

Given the explanatory nature of this study, a simple generalization of our findings should be made with care. However, we believe that our study has made important contributions in 
three areas. First, our study contributes to the ambiguity literature. Beyond the commonly used context of decision making in ambiguity research, we examine the multiple meanings construction processes in a novel setting: ancient poetry-using the logic of appropriateness. The pair-matching process underscores the mechanism by which multiple layers of meaning of poetry can be constructed on the basis of individuals' identities, experiences, desires, and preferences in a particular situation. Our research indicates that the "logic of appropriateness," rather than the "logic of consequences," determines readers and recipients" multiple interpretations of poetry. In addition, we contribute to the conversation of ambiguity as source of intelligence. Our findings reveal two distinct approaches in exploiting the application of ambiguity encapsulated in poetry on contemporary leadership: leaders' selfreflection and strategic tactics to influence others. Referring to the analytical framework on multiple layers of meaning in poetry, leaders can gain wisdom by critically reflecting on and evaluating poetry and poets to cultivate their own leadership behavior. Moreover, leaders could leverage poetry in motivating employees or winning customers through the beauty of its ambiguity. Recipients can be inspired, motivated, and stimulated by leaders' effective use of poetry.

Second, we contribute to leadership research by using poetry as an artistic and enlightening form of story. Ancient poetry deeply rooted in classic philosophical and cultural resources exhibits distinctive properties. For example, researchers have recognized the utility of metaphor in stimulating creativity and imagination (Cornelissen, Holt, \& Zundel, 2011; Cornelissen, Oswick, Christensen, \& Phillips, 2008; Oswick et al., 2002); the potential utility of poetry may go beyond metaphor. Our research exemplifies how poetry and its ambiguity can be leveraged by leaders in practicing leadership. Our findings on ambiguity as a source of intelligence still may be generalized in light of the shared wisdom and affinity between classical Asian thought and contemporary organization theories (Rhee, 2010). Scholars have begun to pay increasing attention to poetry (Page et al., 2013), yet it still is peripheral in organizational and management research (Darmer \& Grisoni, 2011). We believe poetry and other atheistic forms may invigorate and infuse novelty to the mainstream organization research agenda.

Third, with regard to managerial implications, leaders can use ancient poetry intentionally or unconsciously by following the conceptual model of multiple layers of poetic meaning. Leaders could hone their skills by critically reflecting on poetry and poets. Because poetry can be interpreted in multiple ways, its beauty can extend beyond the Chinese context. Leaders might refer to our conceptual framework in leveraging the ambiguity of poetry, which in turn may help promote leadership practices in other contexts. In practice, leaders can also leverage the ambiguity of poetry in managing employees or customers. Ancient wisdom can generate high value for management practice today. A potential line of research that awaits further scholarly investigation is how leaders might effectively learn from poetry. We suggest that self-reflexivity (Xing \& Sims, 2012) might prove to be a helpful lens in exploring this inquiry.

We hope our study sparks scholars' interests in traditional culture and philosophical resources, particularly in a Chinese context. Poetry and other forms of art may contribute to management practice in terms of creativity, inspiration, and enlightenment. We encourage scholars to explore this untapped territory, which we believe can potentially advance organization theory by drawing wisdom from the ancient classical thoughts and ideas. 
Footnotes

1. We thank the anonymous reviewer for recognizing the potential biases of interviewees in favor of recording successful use of poetry. Although we did not inquire either successful or failure stories in our data collection, there was a tendency among leaders to share successful stories while citing poetry. Despite the potential biases of interviewees, our empirical evidence lends support to the theoretical framework of the logic of appropriateness in the context of poetry and leadership.

2. We translated the Chinese poems by integrating previous translation work (Ho, 2012; Liu \& Lo, $1975 ; \mathrm{Xu}, 2005)$ and further modifications to ensure the translation kept both the superficial and evocative meanings of the poems.

\section{References}

Argote, L., \& Greve, H. R. 2007. A behavioral theory of the firm-40 years and counting: Introduction and impact. Organization Science, 18(3): 337-349.

Augier, M. 2004. James March on education, leadership, and Don Quixote: Introduction and interview. Academy of Management Learning \& Education, 3(2): 169-177.

Augier, M., \& Prietula, M. 2007. Historical roots of the a behavioral theory of the firm model at GSIA. Organization Science, 18(3): 507-522.

Bourgeois, V. W., \& Pinder, C. C. 1983. Contrasting philosophical perspectives in administrative science: A reply to Morgan. Administrative Science Quarterly, 28(4): 608-613.

Bryman, A. 2004. Qualitative research on leadership: A critical but appreciative review. The Leadership Quarterly, 15(6): 729-769.

Confucius. BC551/ BC479. The analects/ Confucius. Zhong Hua Shu Ju Press, 2006.

Cornelissen, J. P., Holt, R., \& Zundel, M. 2011. The role of analogy and metaphor in the framing and legitimization of strategic change. Organization Studies, 32(12): 1701-1716.

Cornelissen, J. P., Oswick, C., Christensen, L. T., \& Phillips, N. 2008. Metaphor in organizational research: context, modalities and implications for research-introduction. Organization Studies, 29(1): 7-22.

Coutu, D. 2006. Ideas as art: A conversation with James G. March. Harvard Business Review, 84(10): $82-91$.

Cunliffe, A. L. 2002. Social poetics as management inquiry a dialogical approach. Journal of Management Inquiry, 11(2): 128-146.

Cunliffe, A. L. 2008. Orientations to social constructionism: Relationally responsive social constructionism and its implications for knowledge and learning. Management Learning, 39(2): 123-139.

Cyert, R. M., \& March, J. G. 1963. A behavioral theory of the firm . Englewood Cliffs, NJ: PrenticeHall.

Dailey, S. L., \& Browning, L. 2014. Retelling stories in organizations: Understanding the functions of narrative repetition. Academy of Management Review, 39(1): 22-43.

Darmer, P. 2006. Poetry as a way to inspire (the management of) the research process. Management Decision, 44(4): 551-560.

Darmer, P., \& Grisoni, L. 2011. The opportunity of poetry: Report about poetry in organizing and managing. Tamara Journal for Critical Organization Inquiry, 9(1-2): 5-13.

Diesing, P. 1971. Patterns of discovery in the social sciences. Chicag: Aldine--Atherton.

Gabriel, Y., \& Connell, N. A. D. C. 2010. Co-creating stories: Collaborative experiments in storytelling. Management Learning, 41(5): 507-523.

Gavetti, G., Greve, H. R., Levinthal, D. A., \& Ocasio, W. 2012. The behavioral theory of the firm: Assessment and prospects. The Academy of Management Annals, 6(1): 1-40.

Giles, H. A. 1923. A history of Chinese literature. New York: Grove Press Inc. 
Grisham, T. 2006. Metaphor, poetry, storytelling and cross-cultural leadership. Management Decision, 44(4): 486-503.

Grisoni, L., \& Kirk, P. 2006. Verse, voice and va va voom!: illuminating management processes through poetry. Management Decision, 44(4): 512-525.

Hightower, J.R., \& Yeh, F. C. 1998. Studies in Chinese Poetry. Cambridge: Harvard University Press.

Ho, C. K. 2012. Chinese poetry of Tang and Song dynasties: A new translation. Hong Kong, China: Shangwu Yinshu Guan.

Kuang, Z. 1859/ 1926. Huifeng Cihua (in Chinese). Hong Kong: The Commerce Press.

Li, P. P. 2012. Toward research-practice balancing in management: The Yin-Yang method for openended and open-minded research. In C. L. Wang, D. J. Ketchen, \& D. D. Bergh (Eds.), Research methodology in strategy and management, Vol. 8: 143-171: Bingley, UK: Emerald Group Publishing Limited.

Lin, Y. 1936. My country and my people. London, Toronto: William Heinemann.

Liu, J. 1962. The art of Chinese poetry. London: Routledge \& Kegan Paul.

Liu, W.-c., \& Lo, I. Y. 1975. Sunflower splendor: Three thousand years of Chinese poetry. Bloomington, IN: Indiana University Press.

Liu, Y., Xing, Y., \& Starik, M. 2012. Storytelling as research method: A West-meets-East perspective. In C. L. Wang, D. J. Ketchen, \& D. D. Bergh (Eds.), Research methodology in strategy and management, Vol. 8: 143-171: Bingley, UK: Emerald Group Publishing Limited.

March, J. G. 1978. Bounded rationality, ambiguity, and the engineering of choice. The Bell Journal of Economics, 9: 587-608.

March, J. G. 1994. A primer on decision making: How decisions happen. New York: Free Press.

March, J. G. 2006. Poetry and the rhetoric of management Easter 1916. Journal of Management Inquiry, 15(1): 70-72.

March, J. G. 2010. The ambiguities of experience. Ithaca, NY: Cornell University Press.

March, J. G., \& Olsen, J. P. 1976. Ambiguity and choice in organizations. Bergen, Norway: Universitetsforlaget.

March, J. G., \& Olsen, J. P. 1989. Rediscovering institutions: The organizational basis of politics. New York: Free Press.

March, J. G., \& Olsen, J. P. 2004. The logic of appropriateness, ARENA, Centre for European Studies, Working papers 04/09. University of Oslo: ARENA.

March, J. G., \& Simon, H. A. 1993. Organizations. Oxford: Blackwell.

Melvin, S. 2012. The poetry of Chinese politics. Caixin Online (August 3).

Miao, Y. 1979. Ci Lun in Shi Ci Sanlun (Translated by John Minford: 'The Chinese lyric')

Renditions: A Chinese-English Translation Magazine: 25-44.

Morgan, G. 1997. Images of organization (2 ed.). Beverley Hills, CA: Sage.

Oswick, C., Keenoy, T., \& Grant, D. 2002. Metaphor and analogical reasoning in organization theory: Beyond orthodoxy. Academy of Management Review, 27(2): 294-303.

Page, M., Grisoni, L., \& Turner, A. 2013. Dreaming fairness and re-imagining equality and diversity through participative aesthetic inquiry. Management Learning, Published online before print May 28.

Phillips, N., \& Oswick, C. 2012. Organizational discourse: Domains, debates, and directions. The Academy of Management Annals, 6(1): 435-481.

Pontikes, E. G. 2012. Two sides of the same coin: How ambiguous classification affects multiple audiences' evaluations. Administrative Science Quarterly, 57(1): 81-118.

Rhee, M. 2010. The pursuit of shared wisdom in class: When classical Chinese thinkers meet James March. Academy of Management Learning \& Education, 9(2): 258-279.

Rosile, G. A., Boje, D. M., Carlon, D. M., Downs, A., \& Saylors, R. 2013. Storytelling diamond: An antenarrative integration of the six facets of storytelling in organization research design. Organizational Research Methods, 16(10): 557-580.

Santos, F. M., \& Eisenhardt, K. M. 2009. Constructing markets and shaping boundaries: Entrepreneurial power in nascent fields. Academy of Management Journal, 52(4): 643-671.

Sims, D. 2005. You bastard: A narrative exploration of the experience of indignation within organizations. Organization Studies, 26(11): 1625-1640. 
Sims, D. 2010. Looking for the key to leadership under the lamp post. European Management Journal, 28(4): 253-259.

Tsui, A. S. 2007. From homogenization to pluralism: International management research in the academy and beyond. Academy of Management Journal, 50(6): 1353-1364.

Tsui, A. S. 2009. Editor's introduction-Autonomy of inquiry: Shaping the future of emerging scientific communities. Management and Organization Review, 5(1): 1-14.

Walder, A. G. 2011. From control to ownership: China's managerial revolution. Management and Organization Review, 7(1): 19-38.

Wang, K. 1877/ 1927. Jen-Chien Tz'u-Hua: A study in Chinese literary criticism (Translated by Adele Austin Rickett). Hong Kong: Hong Kong University Press.

Weber, J. M., Kopelman, S., \& Messick, D. M. 2004. A conceptual review of decision making in social dilemmas: Applying a logic of appropriateness. Personality and Social Psychology Review, 8(3): 281-307.

Wengraf, T. 2001. Qualitative research interviewing: Biographic narrative and semi-structured methods. London: Sage Publications Ltd.

Whiteman, G. 1997. Poems from James Bay. Organization \& Environment, 10(2): 191-193.

Xing, Y., \& Sims, D. 2012. Leadership, Daoist Wu Wei and reflexivity: Flow, self-protection and excuse in Chinese bank managers' leadership practice. Management Learning, 43(1): 97-112.

Xu, Y. 2005. Selected poems and pictures of the Song Dynasty. Beijing: China Intercontinental Press. 
TABLE 1 ILLUSTRATIONS OF MULTIPLE LAYERS OF POETRY

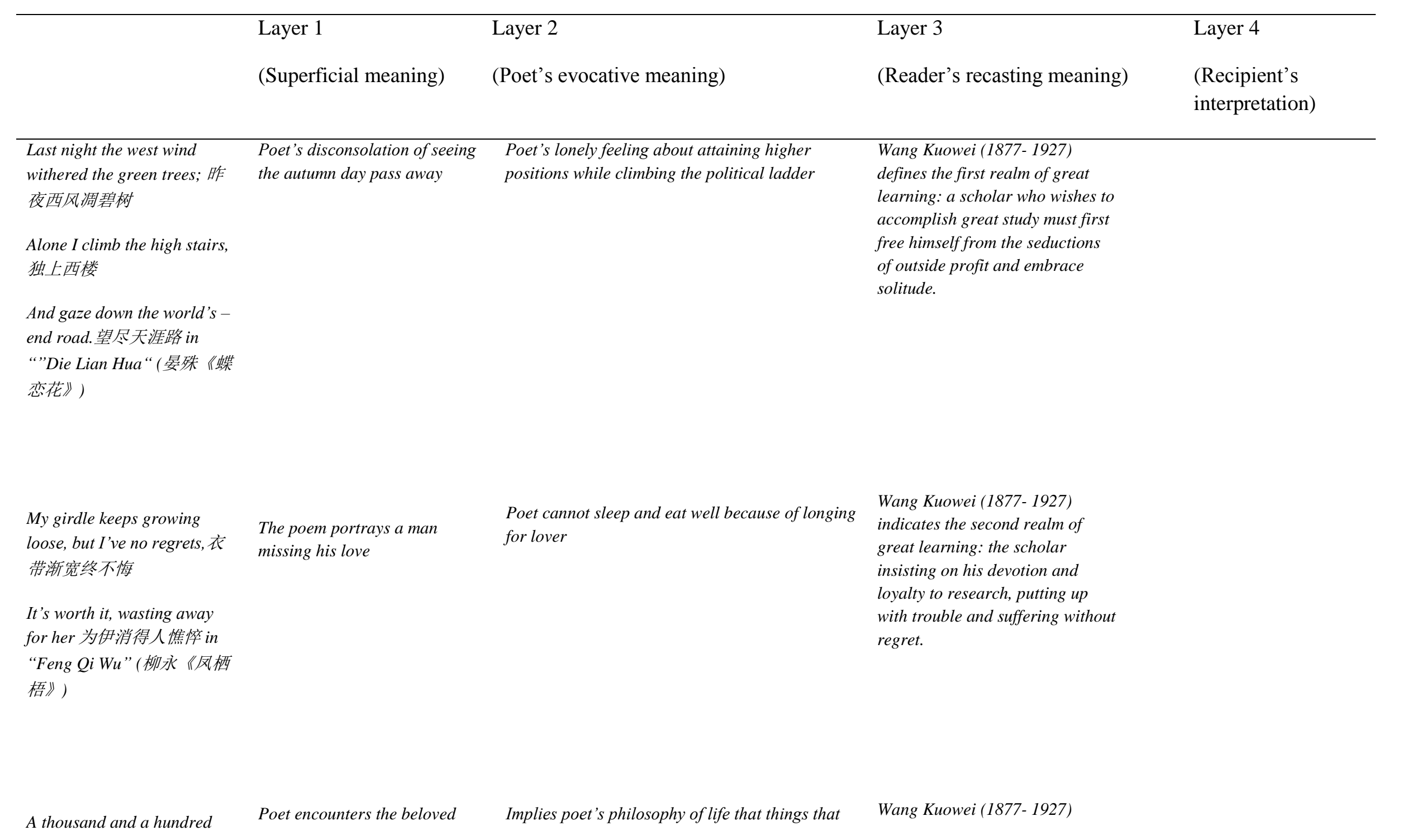


times I looked for her in the

crowd, 众里寻她千百度

interin the evin

of mid-autumn festival

erately seeking for a long time

are attained unexpectedly

Then suddenly, as I turned my

$h e a d$, 蓦然回首

There she was, where the

lanterns were few. 那人却在

灯火阑珊处 in “Qing $Y u A n$ ”

(辛弃疾《青玉案》) identifies the highest realm of

great learning: after hard work

the valuable findings of research

suddenly emerge without any

input by the scholar.
'The red wedding-chamber candles were burning yesterday her husband the day after their 洞房昨夜停红烛

This morning the bride needs to face her parents-in- law. 待 晓堂前拜舅姑

She just finished dressing up herself and asked her

husband meekly: 妆罢低眉问 夫婿

Whether her eyebrows are painted in good fashion? 画店 深浅入时无? in “To Official Zhang after Exam” (朱庆馀 《近试上张水部》)
A conversation between a bride ar Poet likened himself to the bride and his examiner t. Examiner officer understands the wedding. examination paper was well done and whether he poem's superficial meaning (about would receive the government's official appointmen wedding) to the current situationlikened to the examination
The poetry was used as tactic to intrigue examiner's interest for leaving good impression on examiner who was also fond of composing poetry 
'You know I have husband; 君知妾有夫

Yet you give me a pair of pearls. 赠妾双明珠

I feel your love for me, 感君 缠绵意

But I'm loyal to husband,

having vowed to live and die

together. 事夫誓拟同生死

So I have to return the pearls to you with tears down my face; 还君明珠双泪垂

I only regret that we did not meet before marriage.'恨不 相逢未嫁时 in “Song of a Chaste Woman"（张籍《节 妇吟》)

Lotus withers, so does the leaf, however, 荷尽已无擎雨 fading in autumn 盖

The branches of withered

Chrysanthemum hold still. 菊 残犹有傲霜枝 in “Zeng Liu Jingwen”(苏辕《赠刘景
A chaste woman turned down her admirer whom she was also

deeply in love with

fading in autumn
Zhang Ji was a tutor in the imperial academy. His talen was admired by a feudal lord who rebelled against the

country and set up a separatist regime. The lord asked Zhang Ji to work for him. As Zhang Ji dared not to refuse him directly

he wrote the poem and sent it to him. Zhang Ji likened himself to the chaste woman who

appreciated the lord'

recognition and concern but

tactfully rejected his offer

without offending him
The feudal lord understood the meaning beyond the superficial layer and accepted the poet's indirect rejection to his offer.
Poetry is used as a communication device to deliver one's feeling that would otherwise be difficult to express in a more direct manner
Written as a gift to the poet's friend, indicating that both wish to contribute to the country; however although they are old, they can still dream.
Manager uses the poem to praise his boss's character and personality. Although his former superior is retired, he is still dignified with strong mind and body.
As tactic to obtain others' favor and to retain a good personal relationship 
With monkeys' incessantly sad adieus the riverbanks are loud; 两岸猿声啼不住,

My skiff has left myriad mountains far away. 轻舟已 过万重山 in “Leaving Baidi City”(李白《早发白帝城》)

genius emerges every generation, 江山代有人

才出;

all of whom are immortal for hundreds years'各领 风骚数百年 in “Review of Poetry” (赵翼《论 诗》)
To depict a scenery and praise the fast speed of a skiff sculling among mountains.
The poet was dismissed by the Emperor and became Daoist wandering

throughout the country to

dispel his distress.
Manager likens his opponents' criticisms to shouting monkeys, demonstrating a very determined and even aggressive will to carry out reforms.
The manager recontextualized the poem in making sense of his curren situation, which demonstrates his aggressive manner in carrying out reform.
Every nation gives birth to outstanding elites whose influences can carry on for hundreds of year

Poet notes that the great poets appear seldom. however, their poetry's influence may last for hundreds of years
Managers modified the original poem from "several hundred years" to "two or three" years to imply that in the modern fast-paced industry environment, the influence of innovation might only last a short time.
To inspire employees to keep working hard and not to settle for their current achievement 
TABLE 2

\section{LINKS BETWEEN CONTEMPORARY CHINESE LEADERSHIP AND CLASSICAL CHINESE POETRY}

\begin{tabular}{ll}
\hline Category of leaders' application of poetry & Chinese poetry recited in leaders' narratives \\
\hline $\begin{array}{l}\text { Leaders drawing lessons from poets' experience } \\
\text { through critical interpretation of the poem }\end{array}$ & $\begin{array}{l}\text { What really valuable is usually ignored in the historical } \\
\text { record; 糟粕所传非粹美 }\end{array}$ \\
What the best painter cannot show is figural spirit; 丹青难 \\
写是精神 \\
$\begin{array}{l}\text { How can these people with common and ordinary sense } \\
\text { understand thoroughly the thought of talented people of } \\
\text { superior attainment, 区区岂尽高贤意 } \\
\text { What they can only tell (in their historical record or } \\
\text { painting) is only superficial things recorded in the books or } \\
\text { appearance. 独守千秋纸上全 in Wang Anshi “Reading } \\
\text { History” (王安石 《读史》) }\end{array}$
\end{tabular}

Influence on contemporary leadership

Leaders critically question poet's opinion (ignore or discard alternative views) to draw lessons from poet's failure.
Since the world can in no way answer our craving, And Sorrows return, though we drown them with wine, 人生在世 不称意,

I will loosen my hair tomorrow and take to a fishing boat. 明 朝散发弄扁舟 in Li Bai’s “Farewell with Shu Yun in Xuan Zhou Xie Yao Lou” (李白《宣州谢朓楼饯别校书叔云》)
Leaders critique poet's passive feeling toward temporary frustrations in one's political career and argue that even talented employees must conform to the trend and not to give up 
With monkeys' incessantly sad adieus the riverbanks are

loud; 两岸猿声啼不住。

My skiff has left myriad mountains far away. 轻舟已过万重

山 in Li Bai's “Leaving Baidi City”(李白《早发白帝城》)

I'll bend my bow like a full moon, 会挽雕弓如满月

Aiming northwest, 西北望

I will shoot down the fierce Wolf from the sky 射天狼 in $S u$ Shi's “Jiang Cheng Zi, Hunting in Mi Zhou” (苏转《江城

子。密州出猎》)

At the head of the orange island, Along I stand in the autumn chill, Watching the Xiang River flow north still, Lo! Ten

thousand mountains are clothed in red; With feelings and thoughts evoked to my tongue, I cannot help asking the land

so immensely wide and long: Who can hold you up or sink you down? 独立寒秋, 湘江北去, 橘子洲头。问苍茫大

地, 谁主沉浮? in Mao Zedong's “Chang Sha: Spring beaming in garden” (毛泽东《沁园春长沙》)

If a bud opens, gather it 花开堪折直须折
Lest you but wait for an empty bough. 莫待无花空折枝 from
Leader criticized the poet who views the career barrier in the political sphere negatively. In new situation,

leaders cast new meaning into this poem. In contrast to the poet, the leader demonstrates his aggressive manner in carrying out reform even though facing many opposing voices.

Inspired by a heroic poem to choose risk in decision making and professional development.

Standing on the orange island where the poet once stood, the leader feels the morale and spirit of the poet as a great leader in composing this poem and to motivate himself to pursue achievement.

Fitting the poet's rule in the leader's modern situation to guide his dealing with a management predicament leaders' rule of behavior 
Du Qiuniang's “Gold-threaded dress” (杜秋娘《金缕

衣》)

To enjoy when flower is budding,

To appreciate when moon is yet to become round 花末全开 月末圆 in “Tan Hua” (<探花)

enjoy a scholar life after hundreds battles 百战归来再读书

An old steed in the stable still aspires to gallop a thousand miles; A noble-hearted man retains his high aspirations even in old age; (from Cao Cao's “Gui Sui Shou”)老䩀伏杤, 志 在千里, 壮士暮年, 壮心不已。(曹操く, 龟虽寿〉)

The poet had tremendous achievements, even in old age.
Leaders adopting poetry as a tactic to influence others

The weal and woe which stay not in mind will pass by. 险夷 原不滞胸中

Just as the floating cloud sailing across the sky. 何异浮云过 太空

I cross billows for miles and miles at night. 夜静海涛三万 里 The leader used this poem to motivate himself that success is possible even for old people (the leader started up his own venture in his late forties).

Learning from the poet's rule of behavior to be

"knowledgeable to make compromise and to enjoy the second best rather than perfection"; in doing so, the leader can make good collaboration with the other founding partners of the privately owned firm.

\section{Leader used the poem to stimulate staff members} combative spirits. 
下天风 in Wang Yangming's “Sailing in Sea”(王阳明《泛 海》)

Bear the hardship and bitterness before others, 先天下之忧 而忧,

Enjoy comfort and happiness after others'后天下之乐而乐 in Fan Zhongyan's “Yue Yang Lou Ji” (范仲淹 《岳阳楼 记》)

Her impressive manner veiled in her rosy cheek'. 粉面含春 威不露 in Cao Xueqin's “Dream of the Red Chamber” (曹 雪芹《红楼梦》)

Grievances, if too many, would wound seriously one's heart 牢骚太盛防肠断,

Weighing things one should be farsighted over a whole or part 风物长宜放眼量

Say not too shallow here is the water of the Kunming Lake, 莫道昆明池水浅,

It is better than Fuchun River to watch fish for one to take (to the tune of seven-character lu shi) 观鱼胜过富春江 in Mao Zedong's “Qi Lv He Mr. Liu Yazi” (毛泽东 《七律和
Leader used poem to inspire employees in the hope that they can agree with the poet's ideal to put the self after the organization and society and make a wholehearted contribution

Leader used the poem as a communicative tool to gain favor and trust from her customer

Using poetry to tell employees that they should not merely aim high but face the current unfavorable situation with a long-term orientation. 
柳亚子先生》)

Are they born to be noble and privileged? 王侯将相, 宁有 种乎 in Si Maqian's “Record of History” (司马迁《史 记》)

Lotus withers, so does the leaf, however, 荷尽已无擎雨盖

The branches of withered Chrysanthemum hold still. 菊残犹 有傲霜枝 in “Zeng Liu Jingwen” (苏轿《赠刘景文》)

To give one's best, give one's all till one's heart ceases to beat 鞠躬尽瘁, 死而后已 in Zhu Geliang's “Chu Shi Biao” (诸葛亮《出师表》)

Genius emerges every generation, 江山代有人才出

Each of whom is immortal for hundreds years' 各领风骚数 百年in Zhao Yi's “Review of Poetry” (赵翼《论诗》)
Using poetry to warn middle managers that they should not judge employees with bias or only rely merely on an elite educational background but to consider employees professional experience and potential in selecting and promoting subordinates.

Leader used the poem as tactic to praise the old retiring manager to obtain favor and retain a good personal relationship.

Leader used the poem to implicitly convey to his subordinates what kind of talent leaders prefer. Like the poet, it is those who wholeheartedly commit to the organization who will be promoted.

Leader used poem to inspire employees to keep working hard and not to settle for their current achievement 
FIGURE1 POETRY'S MULTIPLE LAYERS OF MEANING AND APPROPRIATENESS OF APPLICATION

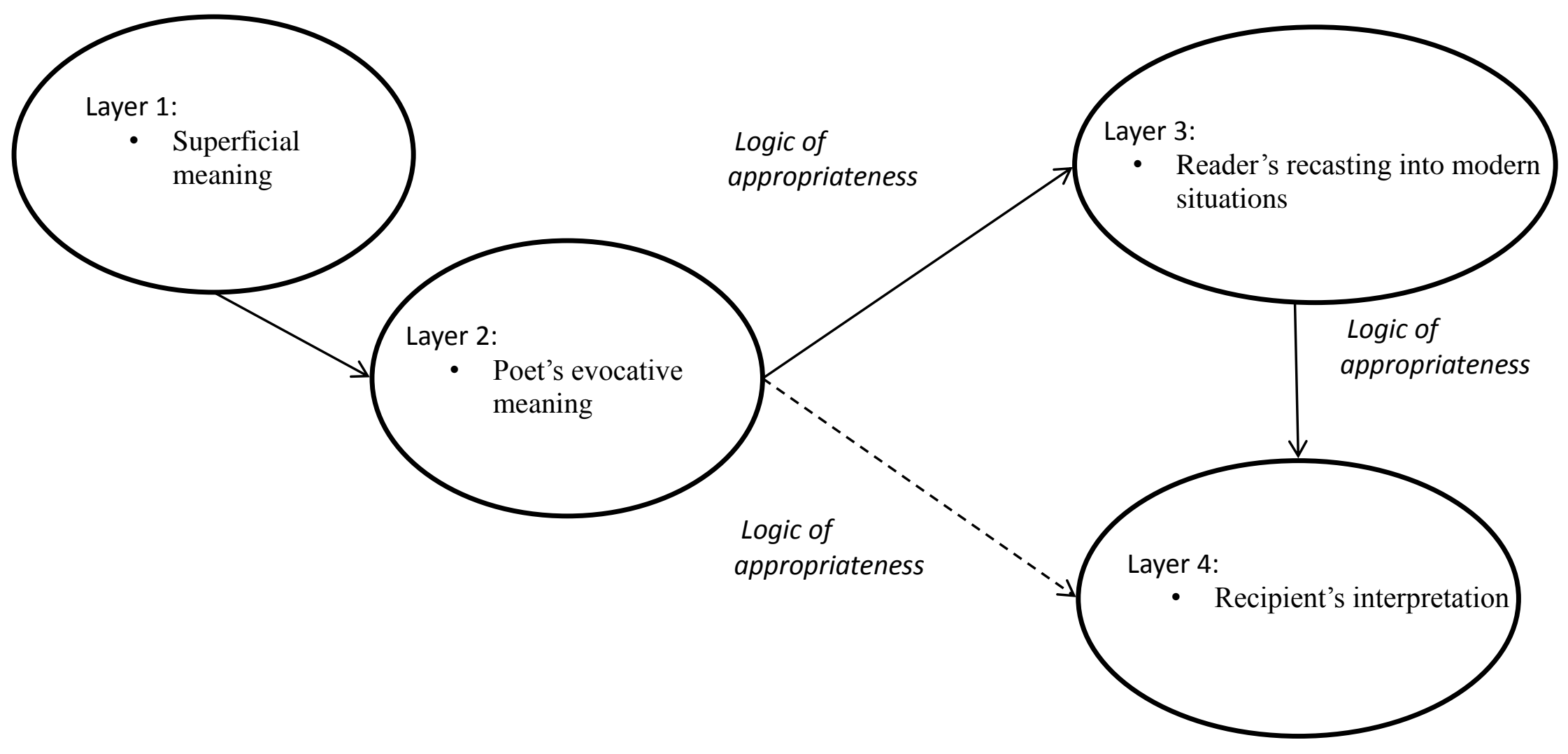


APPENDIX

\section{HISTORICAL DEVELOPMENT OF CHINESE POETRY}

\begin{tabular}{|c|c|c|c|}
\hline Dynasty & Type of Poetry & Form & Example \\
\hline $\begin{array}{l}\text { Early Western Zhou (西周初期) } \\
\left(11^{\text {th }} \text { Century - } 771 \text { B.C. }\right)\end{array}$ & 诗经 Shi Ching, (the Book of Songs) & $\begin{array}{l}\text { A preserved collection of classical } \\
\text { Chinese poetry from over two millennia } \\
\text { ago. Composed of four-character lines }\end{array}$ & $\begin{array}{l}\text { “Zi Jin”〈子衿〉 } \\
\text { O you, with the collar blue, 青青子衿, }\end{array}$ \\
\hline
\end{tabular}

On and on I have been yearning for you. 悠悠我心。

Where you are I cannot go, 纵我不往,

Why you not send a word to me? 子宁不嗣音?

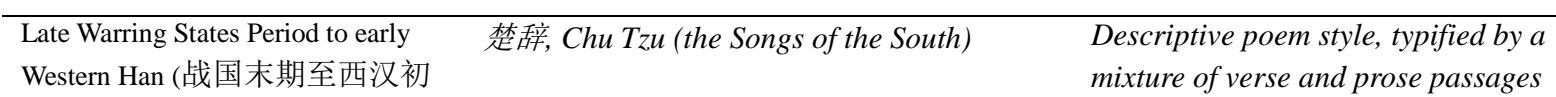

期) $(475-206$ B.C. $)$

mixture of verse and prose passages

“Li Sao” Qu Yuan <离骚> 屈原

The way ahead is long, 路漫漫其修远公

Yet high and low I'll search with my will unbending 吾

将上下而求索

\begin{tabular}{|c|c|c|c|}
\hline $\begin{array}{l}\text { Han (汉) } \\
\text { (206 B.C. - A.D. 220) }\end{array}$ & 汉赋, Han Poetry & $\begin{array}{l}\text { A folk-song style of poetry known as } \\
\text { "Music Bureau” poems for the } \\
\text { government's role in collecting such } \\
\text { poems. Composed of five-character (五 } \\
\text { 言) or seven-character (七言) lines. }\end{array}$ & $\begin{array}{l}\text { “Da Feng Ge” Liu Bang 〈大风歌〉 刘邦 } \\
\text { A great wind comes forth, the clouds are driven away. } \\
\text { 大风起兮云飞扬, } \\
\text { I return to hometown in glory, with the wind under my } \\
\text { sway. 威加海内兮归故乡, } \\
\text { Where can I find brave men, to guard my four } \\
\text { frontiers! 安得猛士合守四方。 }\end{array}$ \\
\hline Six Dynasties (六朝) & 六朝诗, Six Dynasties Poetry (including 晋 & $\begin{array}{l}\text { Building on the traditions and } \\
\text { developed Han poetry into a different }\end{array}$ & “Duan Ge Xing” Cao Cao <短歌行〉曹操 \\
\hline
\end{tabular}




\begin{tabular}{|c|c|c|c|}
\hline$(220-589)$ & 安风骨, Jin'an Poetry) & $\begin{array}{l}\text { form with more personal rather than } \\
\text { impersonal voice. }\end{array}$ & $\begin{array}{l}\text { The wine, the song, life goes on, } \\
\text { But for how long 对酒当歌，人生几何 } \\
\text { It evaporates, to our dismay, } \\
\text { Like the morning dew, day after day 譬如朝露, 去日 } \\
\text { 苦多 }\end{array}$ \\
\hline $\begin{array}{l}\text { Tang Dynasty (唐) } \\
(618-907)\end{array}$ & 唐诗, Tang Poetry & $\begin{array}{l}\text { 古体诗 ancient-style (poetry composed } \\
\text { in unregulated style; 近体诗 recent } \\
\text { style (poetry composed in regulated } \\
\text { tone patterns) includes form of 律诗 } \\
\text { Lushi, regulated verses with an eight- } \\
\text { line form having five, six, or seven } \\
\text { characters per line; form of 辞 Ci, } \\
\text { verse following set rhythmic patterns; } \\
\text { form of 绝句 Jueju (truncated verse), a } \\
\text { four-line poem with five, six, or seven } \\
\text { characters per line. }\end{array}$ & $\begin{array}{l}\text { “Deng Gao” Du Fu 〈登高> 杜甫 } \\
\text { It breaks my heart to see blooming trees near the } \\
\text { tower, 花近高楼伤客心, } \\
\text { From this high vantage, sadness everywhere 万方多难 } \\
\text { 此登临。 } \\
\text { Spring comes from sky on earth and greens River } \\
\text { Brocade, 锦江春色来天地, } \\
\text { The world changes now as then like white clouds o' } \\
\text { er Mount Jade 玉垒浮云变古今。 }\end{array}$ \\
\hline $\begin{array}{l}\text { Song Dynasty (宋) } \\
(960-1279)\end{array}$ & 宋词, Song Poetry & $\begin{array}{l}\text { The form of the Ci 词 (lyric) is written } \\
\text { according to the set rhythms of existing } \\
\text { tunes, each of which has music. Each } \\
\text { Ci poem is labeled to the tune of 'Tune } \\
\text { Name' 词牌 and needs to fit to the } \\
\text { particular pattern which has fixed } \\
\text { tone, rhythm, number of syllables per } \\
\text { line, and the number of lines. }\end{array}$ & $\begin{array}{l}\text { “Yu Mei Ren” Li Yu 〈虞美人〉李显 } \\
\text { Those carved balustrades, those marble terraces } \\
\text { should still be there, 雕栏玉砌应犹在 } \\
\text { Only the rosy cheeks cannot be as fair 只是朱颜改 } \\
\text { How much sorrow, pray, can a person carry? 问君能 } \\
\text { 有几多愁 } \\
\text { Like the spring torrent flowing eastward, without } \\
\text { tarry! 恰似一江春水向东流 }\end{array}$ \\
\hline
\end{tabular}




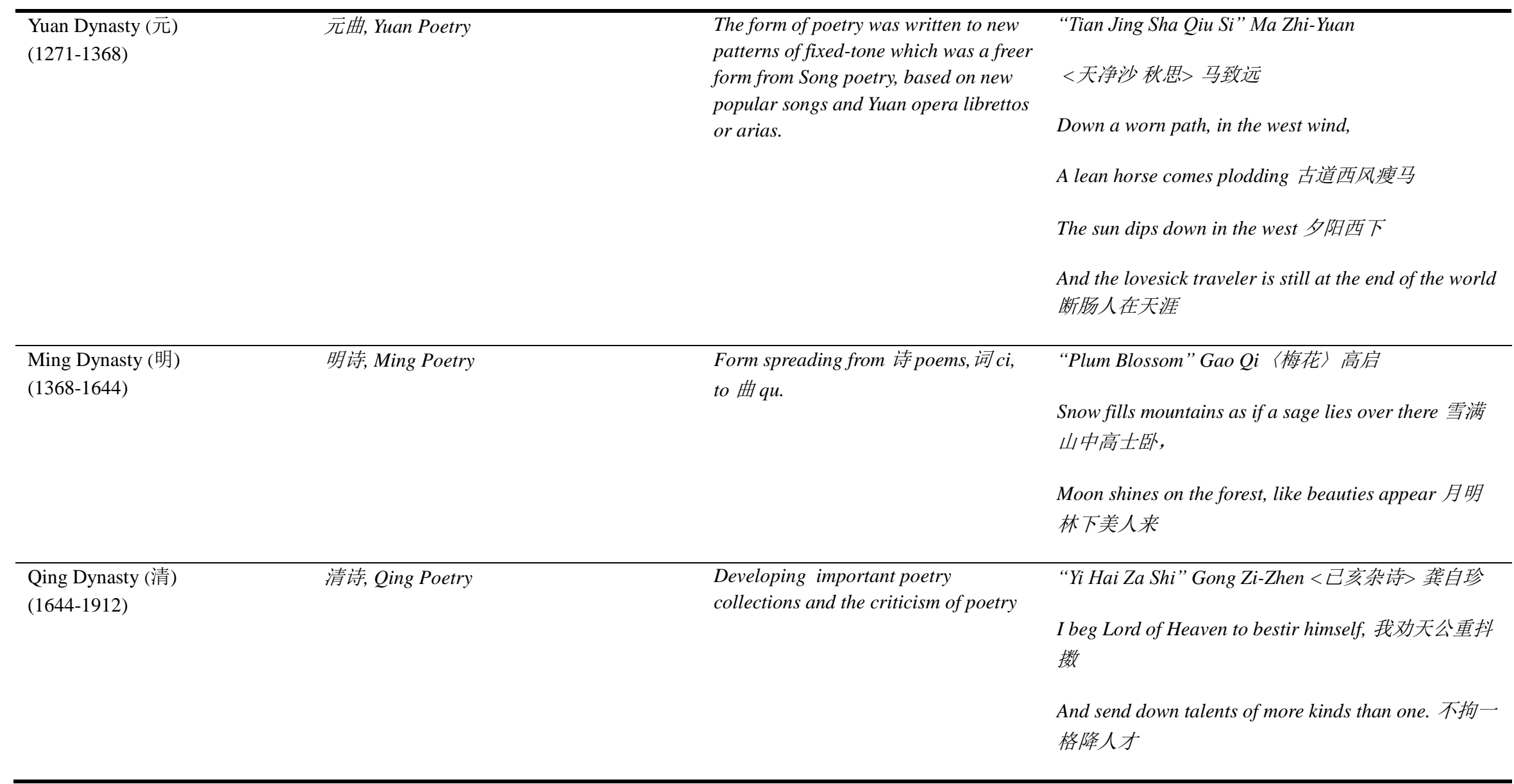


